\title{
Teaching NeuroImages: Adult-onset vanishing white matter disease
}

Rocío-Nur Villar-Quiles, MD, Celia Delgado-Suárez, MD, Manuela Jorquera-Moya, MD, Javier Arpa-Gutiérrez, MD, PhD, and Gloria Ortega-Suero, MD

Neurology ${ }^{\circledR}$ 2018;90:e1091-e1092. doi:10.1212/WNL.0000000000005180
Correspondence

Dr. Villar-Quiles

rocionur@gmail.com

Figure Neuroimaging findings in vanishing white matter disease

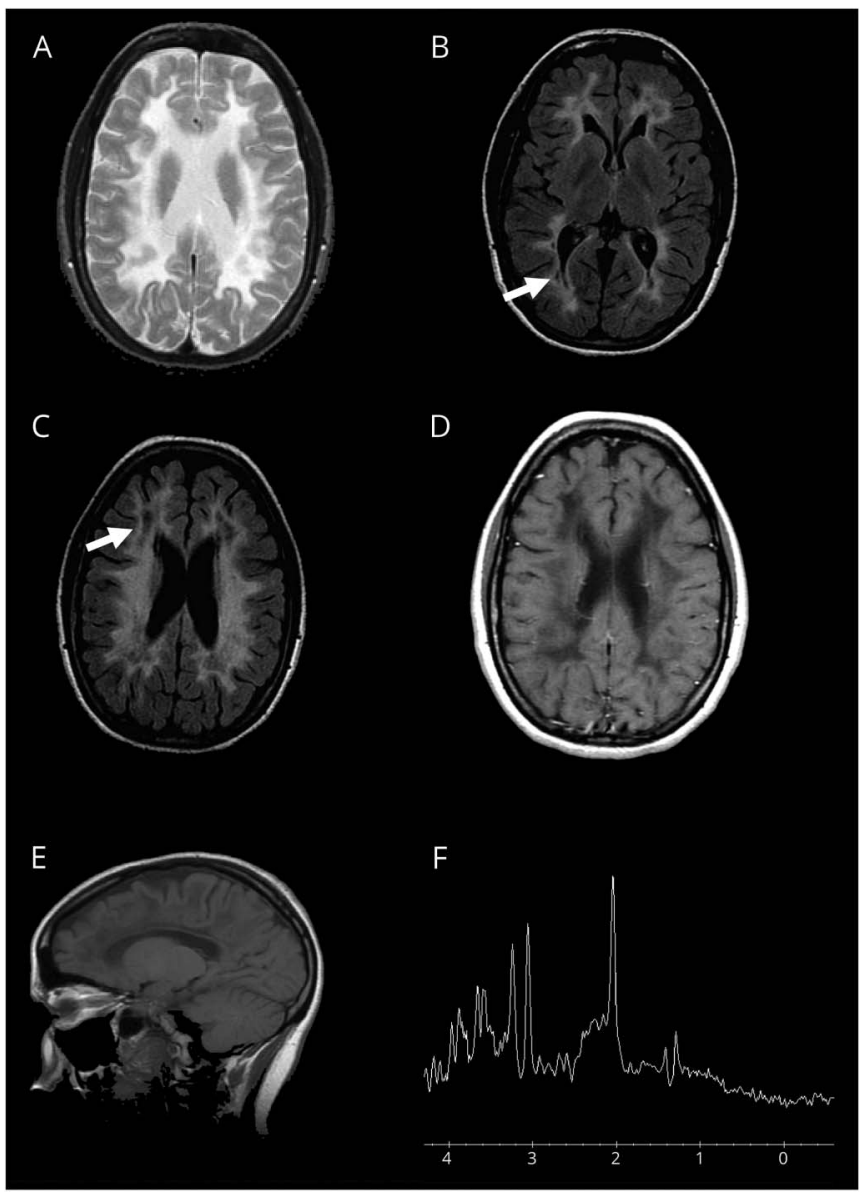

(A) MRI brain axial T2: extensive leukoencephalopathy. (B, C) MRI brain axial T2 fluid-attenuated inversion recovery: diffuse abnormality of the cerebral white matter with evidence of partial cystic degeneration (arrows). (D) MRI brain axial T1+ gadolinium: no contrast enhancement. (E) MRI brain sagittal T1: abnormal white matter signal and thinning of the corpus callosum. (F) Magnetic resonance spectroscopy: mildly elevated lactate peak.

An 18-year-old woman with premature ovarian failure presented with focal motor seizures with secondary generalization and headache 2 weeks after a viral infection. She also had a recent psychological stress background. Examination only revealed generalized hyperreflexia. Neuroimaging studies showed bilateral confluent leukoencephalopathy and periventricular cystic degeneration (figure). Genetic testing showed homozygosity for a p.Arg113His missense mutation in the EIF2B5 gene, confirming the diagnosis of VWM. Phenotypic

\section{MORE ONLINE}

$\rightarrow$ Teaching slides:

links.lww.com/WNL/A264

From the Neurogenetics Section (J.A.-G., G.O.-S.), Department of Neurology, San Carlos Institute for Health Research (IdISSC) (R.-N.V.-Q., C.D.-S.), and Radiology Department (M.J.-M.), Hospital Clínico San Carlos, Madrid, Spain.

Go to Neurology.org/N for full disclosures. Funding information and disclosures deemed relevant by the authors, if any, are provided at the end of the article. 
variation of VWM is extremely wide, with episodes of sudden major neurologic degeneration triggered by febrile infections, minor head trauma, or stressful events. ${ }^{1}$ MRI findings are usually diagnostic and associated with mutations in EIF2B1-5 genes. ${ }^{2}$

\section{Author contributions}

Rocío-Nur Villar-Quiles: acquisition and interpretation of data, manuscript preparation. Celia Delgado-Suárez: acquisition and interpretation of data, manuscript preparation. Manuela Jorquera-Moya: acquisition and interpretation of data, critical revision of manuscript for intellectual content. Javier Arpa-Gutiérrez: critical revision of manuscript for intellectual content. Gloria Ortega-Suero: critical revision of manuscript for intellectual content.

\section{Study funding}

No targeted funding reported.

\section{Disclosure}

The authors report no disclosures relevant to the manuscript. Go to Neurology.org/ $\mathrm{N}$ for full disclosures.

\section{References}

1. van der Knaap MS, Pronk JC, Scheper GC. Vanishing white matter disease. Lancet Neurol 2006;5:413-423.

2. van der Lei HDW, van Berkel CGM, van Wieringen WN, et al. Genotype-phenotype correlation in vanishing white matter disease. Neurology 2010;75:1555-1559. 


\section{Neurology}

Teaching NeuroImages: Adult-onset vanishing white matter disease

Rocío-Nur Villar-Quiles, Celia Delgado-Suárez, Manuela Jorquera-Moya, et al.

Neurology 2018;90;e1091-e1092

DOI 10.1212/WNL.0000000000005180

This information is current as of March 19, 2018

\section{Updated Information \&} Services

\section{References}

Subspecialty Collections

Permissions \& Licensing

Reprints including high resolution figures, can be found at: http://n.neurology.org/content/90/12/e1091.full

This article cites 2 articles, 1 of which you can access for free at: http://n.neurology.org/content/90/12/e1091.full\#ref-list-1

This article, along with others on similar topics, appears in the following collection(s):

All Clinical Neurology

http://n.neurology.org/cgi/collection/all_clinical_neurology All Genetics

http://n.neurology.org/cgi/collection/all_genetics

Leukodystrophies

http://n.neurology.org/cgi/collection/leukodystrophies

MRI

http://n.neurology.org/cgi/collection/mri

Information about reproducing this article in parts (figures,tables) or in its entirety can be found online at:

http://www.neurology.org/about/about_the_journal\#permissions

Information about ordering reprints can be found online:

http://n.neurology.org/subscribers/advertise

Neurology ${ }^{\circledR}$ is the official journal of the American Academy of Neurology. Published continuously since 1951, it is now a weekly with 48 issues per year. Copyright @ 2018 American Academy of Neurology. All rights reserved. Print ISSN: 0028-3878. Online ISSN: 1526-632X.

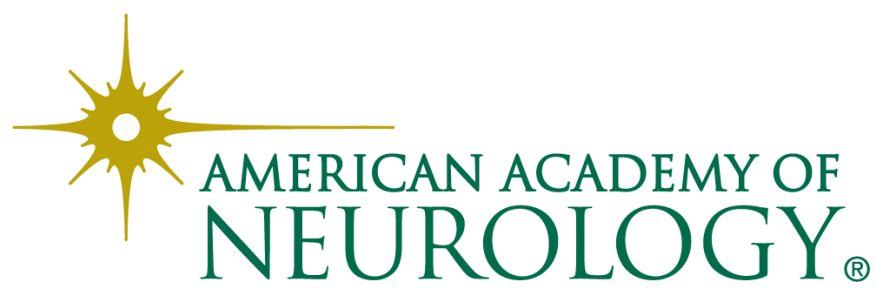

